Marijana Mikić*

\title{
Mind, Body, and Race in Jessie Redmon Fauset's Plum Bun
}

https://doi.org/10.1515/ang-2021-0054

\begin{abstract}
Working at the intersection of cognitive and critical race narratology, the essay examines the relationship between the embodied mind and the social construction of race in Jessie Redmon Fauset's Plum Bun: A Novel Without a Moral (1928/2011). The essay argues that Fauset's African American passing novel rejects the notion of a solely 'inward turn', which is commonly associated with modernist literature, in favor of a more dynamic understanding of embodied cognition that acknowledges the shaping force of race and racialization. Using a seemingly traditional omniscient narrator, Fauset not only draws attention to the failure of U.S. American racial hierarchies, but she also lays bare how race impacts both individual consciousness and social cognition. ${ }^{1}$
\end{abstract}

Key terms: Jessie Redmon Fauset, African American literature, passing, modernism, cognitive narratology, critical race narratology

In her 2017 profile in The New Yorker, Morgan Jerkins labels Jessie Redmon Fauset as the "forgotten" author of the Harlem Renaissance. ${ }^{2}$ Scholarship on Fauset's literary work, including four novels, remains lamentably underdeveloped. But it has also come a long way, from dismissing her novelistic efforts as "old-fashioned, assimilationist, and sentimental” (Sherrard-Johnson 2007: 51) - and perceiving her "to be outside modernist literary circles" (Knopf 1995: ix) - to acknowledging the complexity and modernity of her fiction. ${ }^{3}$ Guy Reynolds, for ex-

1 Acknowledgements: Austrian Science Fund (FWF): P 3118926.

2 In his autobiography, Langston Hughes famously wrote that Fauset was one of the "people who midwived the so-called New Negro Literature into being” (1940/1993: 218). Fauset’s own writing, however, received far less recognition than her work as a literary editor of the Crisis, the literary vehicle for the National Association for the Advancement of Colored People (NAACP).

3 From the 1980s onwards, several scholars began to emphasize the complexities of Fauset's work, whereby especially the feminist readings of Carolyn Wedin Sylvander (1981), Deborah E. McDowell

*Corresponding author: Marijana Mikić, Universität Klagenfurt

E-Mail: Marijana.Mikic@aau.at

Ә Open Access. (C) 2021 Marijana Mikić, published by De Gruyter. (cc)BY the Creative Commons Attribution 4.0 International License. 
ample, positions Fauset's modernism in relation to her literary explorations of "questions about identity and ethnicity" (1999: 89). By writing race into the "social problem novel”, Fauset and other black female modernists of the time, such as Zora Neale Hurston and Nella Larsen, "attempt[ed] to grapple with, and thereby 're-form"' not only the racial problems they addressed, as Reynolds suggests (1999: 89). Their fiction was also a call to 're-form' Eurocentric notions of modernist literature. In his seminal Modernism and the Harlem Renaissance, Houston A. Baker, Jr. writes that "judgements on Afro-American 'modernity' and the 'Harlem Renaissance' that begin with notions of British, Anglo-American, and Irish 'modernism' as 'successful' objects, projects, and processes to be emulated by AfroAmericans are misguided” (1987: xv-xvi). While Harlem Renaissance modernists were drawing on some of the same literary techniques to present subjective experience and consciousness as their 'mainstream' counterparts, their works were authentic and unique in terms of both content and form.

The black passing narrative and its modernist negotiation of 'double consciousness' is a case in point. The fiction of many African American authors of the time, including Fauset, Larsen, James Weldon Johnson, and George S. Schuyler, focused on mixed-race characters who, while legally black in a society governed by racial segregation laws, use their fair-skinned bodies to pass as white. Henry Louis Gates, Jr. has positioned the passing narrative as quintessentially modern, writing that "the thematic elements of passing-fragmentation, alienation, liminality, self-fashioning-echo the great themes of modernism" (1996: n. pag.). The same is true for the modernist interest in consciousness, psychology, and the inner life. Tim Armstrong reminds us that "the dialectic of recognition and misrecognition described by Hegel” is at the core of W. E. B. Du Bois's famous notion of 'double consciousness' and his assertion "that in their struggle for self-expression his people were the first moderns” (2005: 135-136). This dialectic is integral to the psychology of the modernist passing novel which offers fertile ground for an exploration of the relationships between the subjective mind and the racialized body - the "recognition and misrecognition" of self and other - in relation to the socially constructed and unstable category of race.

Working at the intersection of cognitive and critical race narratology, this essay considers the relationship between the embodied mind and the social construction of race in Fauset's Plum Bun: A Novel Without a Moral (1928/2011). ${ }^{4}$ In

(1995), Kathleen Pfeiffer (2002), Susan Tomlinson (2002), and Cherene Sherrard-Johnson (2007) were of critical importance for the reconsideration of her work.

4 The two-way relationship between narrative form, on the one hand, and race and ethnicity, on the other, lies at the heart of what Donahue et al. call a "critical race narratology" (2017: 3). See, for example, Donahue's Contemporary Native Fiction (2019). For cognitive narratological work which 
her critical reconsideration of Fauset as a black female modernist, Knopf argues that "despite the 'traditional' stylistic modes that she used in her fiction, Fauset presents powerful critiques of race, class, and gender hierarchies in American society, critiques that manifest what might usefully be considered a modernist sensibility" (1995: ix). I suggest that it is precisely Fauset's use of a seemingly 'traditional' omniscient narrator that enables her to negotiate race's impact on individual consciousness and social cognition. Taking up David Herman's postCartesian reevaluation of modernist fiction, which suggests that minds "at once shape and are shaped by larger experiential environments" (2011: 249-250), my analysis shows that the narrative minds in the novel are not only embodied but also embedded in a racialized social context. Plum Bun ultimately rejects the notion of a solely 'inward turn', which is commonly associated with modernist literature, in favor of a more dynamic understanding of embodied cognition that acknowledges the shaping force of race and racialization. ${ }^{5}$

\section{The Embodied Mind, Social Cognition, and Race}

Scientific inquiry about how we understand the minds of others (real and fictional) has been rapidly growing in the last decades. Cognitive literary scholar Lisa Zunshine suggests that "the default way by which we construct and navigate our social environment" occurs when "we ascribe to a person a certain mental state on the basis of her observable action" (2006: 6). Zunshine points to a form of (largely unconscious) mind-reading, commonly referred to as theory of mind or theory theory, which suggests that we understand others' minds by theorizing about their mental states based on folk theoretical knowledge. In contrast to that, the simulation theory of mind-reading posits that we understand others' minds by putting ourselves in their shoes and simulating or mirroring their thoughts and

has contributed to what Sue J. Kim calls a "decolonization" of narrative theory by directing attention towards the various and varied literatures of ethnic American authors (2013b: 239), see, for example, Frederick Luis Aldama's Your Brain on Latino Comics (2009); Kim's On Anger (2013a); Alexa Weik von Mossner's Cosmopolitan Minds (2014) and "Feeling Cosmopolitan" (2016); and Stephanie Fetta's Shaming into Brown (2018).

5 In Thinking with Literature: Towards a Cognitive Criticism, Terence Cave suggests that "literature offers a virtually limitless archive of the ways in which human beings think, how they imagine themselves and their world" (2016: 14). Since thinking with African American, and ethnic American literature more broadly, often involves a 'thinking with race', and all the complexities it entails in relation to the storyworld and the real-world, studying the relations between race and narrative form can help us to better understand under-appreciated texts and help us to rethink what we call 'the canon'. 
feelings in our own minds. The discovery of the mirror mechanism in the brain of the macaque monkey, and subsequently in the human brain, in fact, suggests that "our neural circuits are powerfully attuned to the presence, behavior, and emotional display of other members of our species" (Zunshine 2011: 65). Since our brain resists such straightforward classifications that have positioned theory theory and simulation theory as mutually exclusive, the emerging consensus has been that they both likely work in combination. ${ }^{6}$

Given that such mentalizing and simulation mechanisms enable interactions with the world around us, they also impact our ability to make sense of fiction - a narrative representation of the human mind in action. In Fictional Minds, cognitive narratologist Alan Palmer, for instance, suggests: "On the one hand, the reader must have a kind of basic folk theory about how minds work. It is on this basis that we know that motives and dispositions can be ascribed to others. On the other hand, readers also simulate in their own minds the specific dilemmas faced by characters in novels" (2004: 144). What the different theories share in any case is that our understanding of others is automatic and intuitive.

Yet, it is at the same time frequently inaccurate. Nicholas Epley points out that our confidence in theorizing about and/or simulating the minds of others frequently "far outstrips our actual ability" (2014: 12). In this respect, Zunshine points out that "the body is the text that we read throughout our evolution as a social species" (2011: 67; original emphasis). She observes that it "occupies a double position in relation to this cognitive hunger, figuring as both the best and the worst source of information about the mind" (Zunshine 2011: 64). Since we know that others will read us in a certain fashion, we may adapt our observable behavior to influence what people understand, think and feel about us. As a result, "we end up performing our bodies (not always consciously or successfully) to shape other people's perceptions of our mental states" (Zunshine 2011: 67; original emphasis). The expressivity of our material body, which may be both intentional and non-intentional, can thus act as an unreliable signifier in social interactions.

It is this paradox of the body as both a privileged and misleading source of information that the mixed-race figure - who is light-skinned enough to actively encourage or to passively accept being perceived as white by others - exploits to trouble seemingly real assumptions about race in American social life. In a society in which the construct of whiteness offers power and privilege, the passing figure tries to ensure that others read her fair-skinned body as a reliable indicator of her in- or outgroup status. Even though race is a social construct, and not a biological fact, the long history of institutionalized racism and racialized in-and outgroup

6 See, for example, Mitchell et al. (2005). See also, Armstrong (2020: 152-169). 
thinking in the United States has undoubtedly influenced (interactions between) embodied brains. Based on an understanding of the cultural and historical plasticity of the brain, Davidson and McEwen suggest that "[a]mong the influences on brain structure and function that are most powerful in inducing plastic change are social influences [.. .] [t] he brain is constantly being shaped, wittingly and unwittingly, by environmental forces" (2012: 689). Race is one such influence that has been at the forefront of American social life and on the minds of many Americans. When "race becomes 'common sense'-a way of comprehending, explaining or acting in the world" (1994: 60) - as Omi and Winant suggest in their groundbreaking Racial Formation - brain-based cognitive and emotional patterns may become mediated by lived experiences of race and racism.

Various studies in social and cognitive neuroscience have found differences in perception and behavior based on group membership and racial group membership specifically. ${ }^{7}$ Gutsell and Inzlicht, for instance, point to an empathic bias towards outgroup members, which posits that "people are less likely to mentally simulate the simple actions of others when those others belong to a disliked outgroup" (2010: 841). To disrupt such racialized ways of thinking and perceiving that shape the world they live in, passing characters utilize their visually white bodies to tell an alternative story about themselves. In That Middle World: Race, Performance, and the Politics of Passing, Julia S. Charles observes that the "faulty dependence on hair and hue-the suggestion that hair and hue are signifiers of other indelible traits-as a way to determine race and therefore organize a society warrants a collapse of boundaries" (2020: 33). It is because racial in- and outgroup classifications hold enormous social purchase and because the body is an incongruous source of infor-

7 For studies on the influence of various forms of group membership on our brain, see, for example, Eres and Molenberghs (2013); and Molenberghs and Louis (2018). For the impact of race-based group categorizations specifically, see Kubota et al. (2012); Chekroud et al. (2014); and Mattan et al. (2018). While neuroscientific research can offer insight into the ways in which the social construction of race impacts cognition and emotion, it does so in the shadow of a long history of scientific racism. With regard to current neuroscientific research on race, Kahn, for instance, points out that researchers must not engage in a "reduction of racism to merely another form of 'bias' in a manner that erases the distinctive legacy and meaning of racism in the United States", opening the "door to the biologization of racism, which casts it as a neurological or biochemical phenomenon susceptible to biochemical interventions" (2018: viii). Eberhardt, on the other hand, argues that contemporary research may play an important role in "undo[ing] the historical association between neuroscience (as a field) and scientific racism. It offers an alternative model for thinking about race and neuroscience. Surely, it was at the site of the brain that supposedly fundamental and inescapable differences between Whites and Blacks were mapped out initially. In spite of (or precisely because of) this problematic legacy, the brain sciences may currently hold considerable power in undoing these old maps" (2005: 189). 
mation that literary representations of passing can draw attention to the failure of boundaries which exploit essentialist notions of racial difference. ${ }^{8}$

This also means, however, that successful racial passing depends on others' essentialist thinking. The mixed-race character at the center of the black passing narrative, in fact, relies on the visual whiteness of her body as a signifying indicator of her legal and social in- and outgroup status. Drawing on Judith Butler's notion of gender performativity, Catherine Rottenberg argues that "we must understand race as a category of identification and thus as a unique and irreducible modality of performativity" (2008: 32). ${ }^{9}$ Rottenberg's reading of Larsen's Passing (1929/2020) suggests that “subjects are interpellated into the hegemonic social order as gendered and raced beings, and are recognizable only in reference to the existing grid of intelligibility" (2008: 35-36). The race performativity inherent in racial passing therefore disrupts social orders of white normativity and the stability of race as a valid social category, which confirms that "the visible is never easily or simply a guarantor of truth" (Robinson 1994: 719). ${ }^{10}$ Charles observes:

The passing narrative is ripe with racial struggle, which pushes us toward new understandings of how characters of mixed status (re)articulate their identities, negotiate existing racial hierarchies, and exercise greater control over their expressions of selfhood, all of which are means to understanding their social interactions and how their abilities to self-identify affect or threaten previously constructed boarders [sic] of identity. (2020:27)

Literary representations of racial passing in African American novels thus negotiate the limits of the social category of race while highlighting the ways in which race and racialization impact selfhood and intersubjective relations.

Fauset's use of narrative omniscience in her second and arguably most successful of four novels is especially well-suited for an exploration of the passing

8 Cikara and Van Bavel observe that "humans reliably divide the world into us and everyone else: them" (2014: 248; original emphasis), with "the propensity to prefer one's in-group ha[ving] been observed in every culture on earth" (2014: 245). While the tendency to categorize between in- and outgroups, can thus be seen as universal, it is important to stress that categorizations based on race are historically and culturally determined. Cikara and Van Bavel suggest that "one of the major contributions of this recent work [on the neuroscience of intergroup relations] is the demonstration of how flexibly these biological systems represent the self and others [...] [which] implies considerable promise for reducing prejudice and intergroup conflict” (2014: 261).

9 See, for example, Butler's Gender Trouble: Feminism and the Subversion of Identity (1990).

10 In Dislocating the Color Line, Kawash observes that in "the figure of the passing body, the signifiers of race are unloosed from the signifieds; the seeming stable relation between representation and the real collapses, and representation is suddenly dangerous and untrustworthy" (1997: 131132). 
protagonist's and other characters' understanding of self and other. Omniscience importantly informs Plum Bun's modernist representation of the embodied mind embedded in a social world. To show how the characters' engagements with the world are mediated by the social construction of race, Fauset's narrator, who knows more than any and all characters, is passing between different narrative minds. Not only does the representation of the consciousness of different characters mirror the mixed-race figure's ability to oscillate between socially constructed racial categories, but the interplay between the characters' consciousness and the omniscient narrator's voice uncovers the ways in which race impacts individual consciousness as well as inter- and intraracial communication.

\section{Reading Mind, Body, and Race in Plum Bun}

From the outset of the novel, Fauset portrays how socially accepted racial standards inform relationships between characters. While the narrator introduces the entire Murray family as "unpretentious little people" living in "unpretentious little houses" in the 1920s in a middle-class black neighborhood Philadelphia (Fauset 1928/2011: 437), its members are immediately classified according to the color of their skin. The mother and Angela, the protagonist and older of two daughters, are light enough to pass for white, whereas the younger Virginia and her father have darker complexions. Rather than making use of her fair skin only occasionally and for the sake of convenience, it is Angela's biggest wish to be perceived and accepted as white with all the social benefits this entails because "[c]olour or rather the lack of it seemed to the child the one absolute prerequisite to the life of which she was always dreaming" (Fauset 1928/2011: 438-439). Plum Bun thus begins by showing how what Du Bois famously called the twentieth century's "problem of the color-line" (1903/2014: 15) not only created divisions between black and white Americans, but also how it informed (familial) relations among darker- and lighter-skinned African Americans.

The first sentence of the novel tells readers that "Opal Street, as streets go, is no jewel of the first water" and soon it becomes clear that the scenic description of a home with "no allure" is focalized through the character of Angela (Fauset 1928/ 2011: 437). As a fair-skinned black character, the protagonist is characterized by an ambiguous double nature that is mirrored in a narration which alternates between the narrator's and Angela's own voice. When Angela contemplates how her childhood friend Mary rejected her after learning about her racial background, the character's mind is represented through direct thought presentation which is, in turn, mixed with thought reports by the external narrator: 
Angela, too young to define her thoughts, yet felt vaguely: "She failed me once,-I was her friend,-yet she failed me for something with which I had nothing to do. She's just as likely to do it again. It's in her."

Definitely she said to herself, "Mary withdrew herself not because I was coloured but because she didn't know I was coloured. Therefore if she had never known I was coloured she would always have been my friend. We would have kept on having our good times together." And she began to wonder which was the more important, a patent insistence on the fact of colour or an acceptance of the good things of life which could come to you in America if either you were not coloured or the fact of your racial connections was not made known. (Fauset 1928/2011: 461)

The protagonist is not yet passing for white at this point, but she never mentioned race to her friend because she did not think it mattered. Angela's thoughts here represent the growing consciousness of her own racialized position in the world, and her recognition of the potential that her fair-skinned body carries in a society defined by white privilege.

The direct, quoted representation of Angela's consciousness is preceded and followed by the narrator's discourse who first introduces her thoughts and later continues with a report on her thoughts. While direct thought is "the most mimetic and the least mediated category", Palmer argues that thought report is located at the other end of the continuum as the most diegetic and mediated form of thought representation (2008: 603). Following Dorrit Cohn's distinction between dissonant and consonant thought report, Palmer observes that the narrator can adopt varying degrees of overtness (2008: 604). According to Cohn, dissonant thought report is related by "a narrator who, even as he focuses intently on an individual psyche, remains empathically distanced from the consciousness he narrates" (1978: 26). Such narrators offer "[e]xplorations of psychic depth [which] present and evaluate the inner life that the character is occasionally unwilling or unable to see" (Palmer 2008: 604). Plum Bun's omniscient narrator often employs dissonant thought report - not only voicing the characters' consciousness, but also quite deliberately evaluating it - to highlight how race may impact and endanger individual and social cognition. When the two girls try to patch up their friendship, it is revealed that "Mary, who had never thought of speaking of colour, was suddenly conscious that there was a subject which she must not discuss" (Fauset 1928/2011: 461). Not only do readers learn how race begins to impact Angela's own consciousness, but also how the sudden awareness of racial difference compromises the interactions between the two (former) friends.

The following passage illustrates how the narrator's presence is explicitly marked in the novel, drawing attention to Angela's limited perspective of the storyworld and her incorrect reading of her own (non-transparent) mind: 


\begin{abstract}
She drew for herself certain clearly formed conclusions which her subconscious mind thus codified:

First, that the great rewards of life--riches, glamour, pleasure,--are for white-skinned people only. Secondly, that Junius and Virginia were denied these privileges because they were dark; here her reasoning bore at least an element of verisimilitude but she missed the essential fact that her father and sister did not care for this type of pleasure. The effect of her fallaciousness was to cause her to feel a faint pity for her unfortunate relatives and also to feel that coloured people were to be considered fortunate only in the proportion in which they measured up to the physical standards of white people. (Fauset 1928/2011: 441)
\end{abstract}

While it starts as a mere description of the thoughts that Angela harbors in her mind, the narrator increasingly emphasizes that her arguments are faulty. Readers learn that Angela's strong beliefs, shaped by her racialized social circumstances, make her misinterpret the psychology of others. In order to illustrate the protagonist's own embeddedness in racialization processes, the narration moves seamlessly from introducing and reporting the character's thoughts to commenting on them. Palmer points to "the ability of thought report to link the thought processes of individual characters to their environment, and thereby demonstrate in very concrete and specific ways the social and active nature of thought as mental functioning” (2008: 604). This allows readers to see, as Kathleen Pfeiffer suggests, that Angela partakes "in the same cultural predisposition to stereotype that her [subsequent] passing for white essentially seeks to dissolve” (2002: 122). And it enables them to read her in a way that will only later become possible for Angela herself as the narrative progresses in conjunction with her changing perspective on race and racial passing.

The narrative techniques of slipping into and expressing a character's consciousness can be described as a sort of double-voiced discourse, which, according to Paul B. Armstrong, "becomes double and split with the me of the character's consciousness expressed by the me of the narrator's language" (2020: 156). While Armstrong refers to free indirect discourse in particular, I would like to suggest that the "me of the character's consciousness" in the previously quoted passage is doubled by the me of the omniscient narrator who has insight into what Angela herself is not (yet) conscious of. Narrative omniscience is of course not something that is replicating ordinary real-world experience, but the intuitive understanding of the minds of others is. Here, an interesting link can be established to the experimental "evidence that we are more accurate in recognizing the causes of the behaviour of others than we are at recognizing the causes of our own behavior" (Frith 2012: 2216; see also Armstrong 2020: 154). What is (momentarily) inaccessible to the character, but accessible to the narrator, enables readers to know more than the character does. The narrator's own mind-reading creates an interplay between narrator and character consciousness, giving readers privileged access into the 
character's mind, but the narrator's overt presence and mediation nevertheless prevents readers from knowing Angela's “self-for-herself” (Armstrong 2020: 155). Importantly, however, Fauset's use of such a double-voiced discourse allows insight into how “characters' minds operate in a social and physical context” (Palmer 2008: 604), highlighting race's impact on the understanding of self and other.

In The Social Imperative: Race, Close Reading, and Contemporary Literary Criticism, Paula Moya argues that analyzing race through "narrative structure invites us to interrogate the historically- and culturally-situated schemas that guide each character's perception of every other" (2016: 146). By giving insight into how Angela's perception becomes increasingly influenced by learned and habitual patterns of racialization that have taught her to understand both herself and others through a racialized double gaze, Fauset's double-voiced narration formally mirrors Du Bois's suggestive metaphor of “double consciousness", which he described as the "sense of always looking at one's self through the eyes of others" (1903/2014: 8). "[T]he concept of double consciousness and the bivocality inherent in African American novels" (Gallego 2003: 31) is therefore also inherent in Plum Bun's formal and thematic negotiation of the ways in which race and racialization may impact lived experience and the perception of self and other.

Angela's internalized beliefs in black inferiority and her recognition of white power soon tempt her to permanently pass as white. She leaves her home in Philadelphia and moves to a white Manhattan neighborhood where she adopts a new name, Angelé, along with a new social identity. Determined to have a high social standing, she readily answers the courting of Roger Fielding - a white and rich, but openly racist bachelor. When Angela goes to the train station to meet her sister Virginia, who has decided to leave their home in Philadelphia as well and move to Harlem, New York, she accidentally runs into Roger and publicly rejects her sister. The narrator articulates Angela's subjective experiences, observing that "[f]or the first time in the pursuit of her chosen ends she began to waver" (Fauset 1928/2011: 536). While "[a] sick distaste for her action, for her daily deception, for Roger and his prejudices arose within her”, it is accompanied by "a dark anger against a country and a society which could create such an issue" (Fauset 1928/2011: 538). Here we can see how Fauset draws on traditional representations of love and betrayal in literature, but how she expands and criticizes those representations through the lens of race, and more broadly class and gender. In The Changing Same, Deborah E. McDowell observes that "[a]n inherently self-reflexive novel, Plum Bun, like the protagonist whose story it tells, is passing” (1995: 76). Fauset's modernism is thus shaped by her awareness of the power of generic forms, including the conventions of romance and narrative omniscience, which she uses "to reconfigure them, if not pass beyond them altogether" (McDowell 1995: 76; original emphasis). In this defining moment in the novel, Angela starts questioning her 
choice to perform cultural whiteness and deeply regrets her behavior, but she still tries to justify it by arguing that acknowledging Virginia would not have changed her sister's situation, while everything she dreamt of would be lost.

Focalized through Angela, readers learn how the passage prompts her "to picture the tumult of emotions in her sister's mind" (Fauset 1928/2011: 536-537). Several pages later, when Angela tries to apologize for her behavior, the situation is focalized through the consciousness of Virginia, who recapitulates the moment at the train station and then remembers how "it had been possible in slavery times for white men and women to mistreat their mulatto relations, their own flesh and blood, selling them into deeper slavery in the far South or standing by watching them beaten, almost, if not completely, to death" (Fauset 1928/2011: 542). Fauset's use of multiple internal focalization, to narrate the same event through a different character-focalizer - both however in the narrator's words - invites readers to engage with Virginia's judgement of her sister's behavior. In so doing, the novel strategically draws on the characters' different perspectives to direct "readers away from us/them binaries (too often figured in terms of black/white, female/male, or worker/capitalist dichotomies)" (Moya 2016: 145). While readers' empathy is likely to change according to the focalizer - Angela or Virginia -, in both cases the text invites sympathy for the abandoned Virginia based on "the unfairness or unpleasantness" of her situation, which confirms Howard Sklar's argument that empathy may well be a precursor for sympathy, but that it does not necessarily act as a prerequisite (2013: 48). What seems more important, however, is what Sklar asserts in his analysis of Philip Roth's story "Eli, the Fanatic" (1994), namely that readers are invited "to continually negotiate the various - indeed, subjective - versions of reality that the interaction between people (and especially between people of widely different backgrounds) presents" (2013: 76; original emphasis). Whereas Plum Bun does not include fantastic elements, like Roth's story, Fauset uses the revelation of diverging consciousnesses to draw attention to the ways in which race influences interactions between people (who may even belong to the same family) and encourage her diverse readerships to reevaluate their own emotional, embodied, and embedded relations to the world and real-world others. ${ }^{11}$

11 Storyworlds are products of an author's embodied and embedded mind, and, by extension, they engage readers' embodied and embedded minds. Since American social life has historically been, and continues to be, deeply marked by the social construction of race (in many different and changing ways), black readers' engagements with Plum Bun - and African American storyworlds more generally - are likely to, in some ways, differ from the engagements of non-black readerships because of the different ways in which race affects their consciousness and lived experience. In addition to that, contemporary reading experiences of Plum Bun likely differ from narrative encounters with the novel that were embedded in the sociohistorical context of the 1920s and 30s. 
Especially those instances of failed inter-character empathy in the storyworld highlight the painful misconceptions that may be caused by habitual patterns of racialization. The passing character's defiance of social conventions and the suppression of her true feelings complicates others' understanding of her, which is especially represented in her troubled relationship with Roger. When Angela silently observes how Roger orders the headwaiter to throw out an African American family who want to have dinner at the same restaurant, this changes her attitude towards him, but her outward appearance and behavior show very little of her feelings. Instead, Angela silently "turned back to her plate, her heart sick" (Fauset 1928/2011: 518). Since Roger is unaware of her racial background, her bodily performance must not reveal how and why she is so mortified. Pfeiffer describes this as Angela's "parallel experience as a spectator" who does not act but merely watches "the show in the dark; alienated and unconnected" (2002: 120). Although Angela has successfully redrawn power relations for herself by passing for white, her inability to act in this situation leaves her socially immobile. Whereas Roger's behavior at the restaurant represents the racialized social conventions of the time, which put white Americans in a position of great social power, it is a degrading experience for the African American family. Here, Angela occupies what Charles calls "that Middle World [. . .] a space separate from yet bordering on the Black and white worlds" (2020: 23). Readers share Angela's critical double vision of the restaurant scene - her feelings of shock and anger in reaction to Roger's unspeakable actions as well as her experience of empathic pain with the African American family.

Since it is the narrator who relates her thoughts and feelings to readers, Angela's double vision is (again) expressed through a double-voiced discourse which allows readers to see and feel with her, while also observing her as she herself silently observes the situation. What Charles describes as the mixed-race figure's "both-and rather than either-or" position in the world (2020: 30-32; original emphasis) also relates to the 'both-and' of readers' simulations of the narrative. As with real-world simulations of others' minds, simulations of narrative minds depend on both-and relations that "seem to entail a doubling of me and not me" (Armstrong 2020: 166). It is this "merger of subjectivities" (Armstrong 2020: 159) that allows us to understand others who are always both like ourselves and not like ourselves. Preconceived sociocultural conceptions of who is not like ourselves can, however, have a negative effect on our understanding of those unlike ourselves based on differences such as race, ethnicity, class, gender, sexuality, and religion. Plum Bun illustrates that race is one such categorization that is at the forefront of American social life, while it continuously points to "the failure of race to impose stable definitions of identity, or to manifest itself in a reliable, permanent, and/or visible manner" (Wald 2000: ix). Rooted in the tradition of the 
black passing novel, Fauset's representation of her characters' consciousness mirrors the doubling inherent in our real-life relations to others, drawing particular attention to how racialization complicates lived experiences of (inter)subjectivity.

In this situation, Angela herself is tormented by what Du Bois has called "two unreconciled strivings” (1903/2014: 8). For the African American family, however, she becomes part of "the tape of a world that looks on in amused contempt and pity” (Du Bois 1903/2014: 8). Through her social performance of whiteness and her silent complicity in the racist act, she is likely to be stereotypically read as an 'entitled white woman' by the black characters. Whereas passing enables Angela to escape the anti-black racism that she faced while growing up, she becomes entangled in anti-black thought and oppression herself. After she comes home from the restaurant, the narrator reveals that she even feels triumphant because "[l]ife could never cheat her as it had cheated that coloured girl this evening" (Fauset 1928/2011: 521). On the one hand, the complexities underlying the passing protagonist's subjective experience of race draw attention to the shifting and malleable patterns of racial difference which inform in- and outgroup classifications. On the other hand, Fauset's usage of double-voiced discourse to represent Angela's subjective experiences of passing entails a reconfiguration of double consciousness on the level of narrative form. The restaurant situation demonstrates particularly well how Fauset 're-forms' the exploration of character consciousness, a typically modernist trait, to draw attention to the complex relations between embodied consciousness and the racialized social world her characters inhabit.

The irony of the situation, of course, is that Roger is having dinner with a black woman, which he interrupts to remove a black family from the restaurant because they are “spoiling white people's appetites" (Fauset 1928/2011: 518). Interracial communication is shown here to be defined by social cognition that is influenced by racist stereotypes, causing misjudgments. After the black family has been forced to leave the restaurant, Roger asks Angela if it made her "sick to see them" (Fauset 1928/2011: 519), but "[s]he was silent, lifeless" as "[h]e went on recounting instances of how effectively he had 'spoked the wheel' of various coloured people” (Fauset 1928/2011: 518). An involuntary emotional transfer, or "emotional contagion", that occurs when "people nonconsciously and automatically mimic their companions' fleeting expressions of emotion" (Hatfield et al. 1993: 96) likely causes an automatic transfer of Angela's emotions to Roger. ${ }^{12}$ But

12 What Hatfield et al. (1993) refer to as "emotional contagion" is related to Vittorio Gallese's theory of embodied simulation, which he defines as an "automatic, pre-reflexive and unconscious" process that creates "a shared interpersonal space” (2003: 525). Gallese conceptualizes embodied simulation as the basis of empathy, arguing that "our understanding of interpersonal relations 
even though he recognizes that she is upset, Roger believes that she is still disgusted by the whole incident and reveals that he "could tell that night at Martha Burden's by the way you looked at that girl that you had no time for darkies" (Fauset 1928/2011: 518). His mind-reading abilities, however, completely deceive him because Angela's gaze at the African American woman was based on her feeling of astonishment "to observe how the warmth of her appearance overshadowed or rather overshone everyone else in the room" (Fauset 1928/2011: 506). The passage lays bare how theories and simulations of other people's inner states heavily rely on context, and that they might be spectacularly incorrect.

While the effortless and intuitive understanding of others' embodied minds is a universal aspect of human cognitive life, Prinz et al. remind us that this "universal mental form" is also shaped by "interaction with external sources" (2005: 2). Roger's understanding of others' minds is framed by the social conventions of the United States in the early twentieth century and the pre-established structures used to classify others. Whereas Roger empathizes with Angela so effortlessly at the restaurant, albeit incorrectly and for the wrong reasons, he is oblivious of the humiliation and sorrow of the African American family. He even reveals how he "blackballed" many African Americans throughout his life and how glad he would be to financially contribute to the back-to-Africa movement (Fauset 1928/ 2011: 518-519). This exemplifies what Gutsell and Inzlicht call "reduced mental simulation" for "those categorized as members of an outgroup" (2010: 841). When Roger brings Angela home after dinner and she leaves "him staring and nonplussed on the sidewalk", the narrator slips into his consciousness to reveal his confusion: "But she likes me. I'd have sworn she liked me to-night. Those damn niggers! I bet she's thinking about me this minute" (Fauset 1928/2011: 519). In the following sentence the narrator, however, makes Roger's fallaciousness explicit: "He would have lost his bet. She was thinking about the coloured people" (Fauset 1928/2011: 519). The narrator's ability to pass between different minds repeatedly foregrounds the failure of social cognition based on seemingly stable racial classifications. Whereas neuroscientist Christian Keysers suggests that the "human brain is wired to be empathetic" (2012: 216), Saucier argues that "individuals' perception of race as a biological distinction" can hinder empathic behavior (2015: 401). The restaurant situation not only demonstrates the importance of the social construction of minds within the storyworld, it simultaneously highlights the real-world dynamics between our universal cognitive architecture and the cognitive-affective socialization that growing up in a racialized society can entail.

relies on the basic capacity to model the behaviour of other individuals by employing the same resources used to model our own behaviour" (2003: 525). 


\section{Conclusion}

Angela is drawn back to Philadelphia towards the end of the novel, which constitutes what McDowell calls "a kind of primal scene in African American fiction" (1995: 70). The experience of returning to her roots, however, fails when Angela is rejected as "nothing but poor white trash" by the black woman who now lives in their old family home (Fauset 1928/2011: 674). According to McDowell, Angela is “without color and is thus, in terms of U.S. racial semantics, without 'race,' but the black woman assigns her a race and marks her with the stigma of a degraded class" (1995: 70). Finding herself in a black neighborhood, Angela experiences what McDowell calls a "re-marking" (1995: 70) as she is rejected based on the very same unstable process of reading race onto the bodies of others that enabled her racial passing. The narration of Angela's performance of, and confrontation with, race not only demonstrates the failure of U.S. America's racial system, but it also draws attention to the complex relationships between embodied mind and racialized environment, encouraging readers to reflect on their own embodied and embedded relations to real-world others.

Using a cognitive and critical race narratological approach, I have argued that narrative omniscience serves as an important tool for representing the relationships between embodied narrative minds and the social construction of race in Plum Bun. The duality that shapes the thematic concerns of the passing narrative is likewise expressed in the double-voiced literary representation of racialized embodied experiences. On the one hand, the analysis of embodied cognition and race in this essay points to the relevance of a post-Cartesian revaluation of the mind in modernist fiction, "taking issue", as Herman proposes "both with internalist or cognitivist conceptions of the mind and with efforts to align modernist narratives with such internalist models" (2011: 22). On the other hand, the passing narrative's representation of (double) consciousness entails a reconfiguration of modernist renderings of subjective experience, which points to the importance of studying race as a fundamental aspect of black modernist form.

Plum Bun shows, as Fauset observes in her 1922 essay "Some Notes on Color”, how "the puzzling, tangling, nerve-wracking consciousness of color envelops and swathes" its characters (2003: 367). In so doing, it illuminates the dynamics and paradoxes between embodied narrative minds and the racialized storyworld they inhabit. If the sociocultural, political, and cognitive aspects that impact race and racialization sometimes remain obscure in our real-life interactions, literature offers us "the capacity to decipher the durable racial grammar that structures racialized hierarchies and frames the narrative of our republic" (Guinier 2004: 100). My analysis of the relationship between mind, body, and race in the novel - while 
crucially invested in the critical reconsideration of Fauset's modernism - is but an example of how literary texts by African American and ethnic American authors can contribute to a better understanding of the ways in which universally-shared and culturally-specific patterns of cognition and emotion converge in different narratives.

\section{Works Cited}

Aldama, Frederick Luis. 2009. Your Brain on Latino Comics: From Gus Arriola to Los Bros Hernandez. Austin, TX: University of Texas Press.

Armstrong, Tim. 2005. Modernism: A Cultural History. Cambridge: Polity Press.

Armstrong, Paul B. 2020. Stories and the Brain: The Neuroscience of Narrative. Baltimore, MD: Johns Hopkins University Press.

Baker, Houston A., Jr. 1987. Modernism and the Harlem Renaissance. Chicago, IL: University of Chicago Press.

Butler, Judith. 1990. Gender Trouble: Feminism and the Subversion of Identity. New York: Routledge.

Cave, Terence. 2016. Thinking with Literature: Towards a Cognitive Criticism. Oxford: Oxford University Press.

Charles, Julia S. 2020. That Middle World: Race, Performance, and the Politics of Passing. Chapel Hill, NC: University of North Carolina Press.

Chekroud, Adam M., Jim A. C. Everett, Holly Bridge and Miles Hewstone. 2014. "A Review of Neuroimaging Studies of Race-Related Prejudice: Does Amygdala Response Reflect Threat?” Frontiers in Human Neuroscience 8: 179.

Cikara, Mina and Jay J. Van Bavel. 2014. "The Neuroscience of Intergroup Relations: An Integrative Review". Perspectives on Psychological Science 9.3: 245-274.

Cohn, Dorrit. 1978. Transparent Minds: Narrative Modes for Presenting Consciousness in Fiction. Princeton, NJ: Princeton University Press.

Davidson, Richard J. and Bruce S. McEwen. 2012. "Social Influences on Neuroplasticity: Stress and Interventions to Promote Well-Being”. Nature Neuroscience 15.5: 689-695.

Donahue, James J., Jennifer Ann Ho and Shaun Morgan (eds.). 2017. Narrative, Race, and Ethnicity in the United States. Columbus, OH: Ohio State University Press.

Donahue, James J. 2019. Contemporary Native Fiction: Toward a Narrative Poetics of Survivance. New York: Routledge.

Du Bois, W. E. B. 1903/2014. The Souls of Black Folk. Oxford: Oxford University Press.

Eberhardt, Jennifer L. 2005. “Imaging Race”. American Psychologist 60.2: 181-190.

Epley, Nicholas. 2014. Mindwise: Why We Misunderstand What Others Think, Believe, Feel, and Want. New York: Knopf.

Eres, Robert and Pascal Molenberghs. 2013. "The Influence of Group Membership on the Neural Correlates Involved in Empathy”. Frontiers in Human Neuroscience 7: 176.

Fauset, Jessie Redmon. 1922/2003. “Some Notes on Color”. In: Janet Witalec (ed.). Harlem Renaissance: A Gale Critical Companion. Detroit, MI: Gale. 365-367.

Fauset, Jessie Redmon. 1928/2011. Plum Bun: A Novel Without a Moral. Harlem Renaissance: Five Novels of the 1920s. Ed. Rafia Zafar. New York: The Library of America. 433-686. 
Fetta, Stephanie. 2018. Shaming into Brown: Somatic Transactions of Race in Latina/o Literature. Columbus, $\mathrm{OH}$ : Ohio State University Press.

Frith, Chris D. 2012. "The Role of Metacognition in Human Social Interactions". Philosophical Transactions Royal Society B 367: 2213-2223.

Gallego, Mar. 2003. Passing Novels in the Harlem Renaissance: Identity Politics and Textual Strategies. Münster: LIT.

Gallese, Vittorio. 2003. "The Manifold Nature of Interpersonal Relations: The Quest for a Common Mechanism”. The Royal Society 358: 517-528.

Gates, Henry Louis, Jr. 1996. "White Like Me.” The New Yorker June 17. <https://www.newyorker.com/magazine/1996/06/17/white-like-me> [accessed 02 May 2021].

Guinier, Lani. 2004. "From Racial Liberalism to Racial Literacy: Brown v. Board of Education and the Interest-Divergence Dilemma”. Journal of American History 91.1: 92-118.

Gutsell, Jennifer N. and Michael Inzlicht. 2010. "Empathy Constrained: Prejudice Predicts Reduced Mental Simulation of Actions during Observation of Outgroups". Journal of Experimental Social Psychology 46.5: 841-845.

Hatfield, Elaine, John T. Cacioppo and Richard L. Rapson. 1993. “Emotional Contagion”. Current Directions in Psychological Science 2.3: 96-99.

Herman, David (ed.). 2011. Emergence of Mind: Representations of Consciousness in Narrative Discourse in English. Lincoln, NE: University of Nebraska Press.

Hughes, Langston. 1940/1993. The Big Sea. New York: Hill and Wang.

Jerkins, Morgan. 2017. “The Forgotten Work of Jessie Redmon Fauset”. The New Yorker February 18. <https://www.newyorker.com/books/page-turner/the-forgotten-work-of-jessieredmon-fauset> [accessed 02 May 2021].

Kahn, Jonathan. 2018. Race on the Brain: What Implicit Bias Gets Wrong About the Struggle for Racial Justice. New York: Columbia University Press.

Kawash, Samira. 1997. Dislocating the Color Line: Identity, Hybridity, and Singularity in AfricanAmerican Narrative. Stanford, CA: Stanford University Press.

Keysers, Christian. 2012. The Empathic Brain: How the Discovery of Mirror Neurons Changes Our Understanding of Human Nature. Lexington, KY: Social Brain Press.

Kim, Sue J. 2013a. On Anger: Race, Cognition, Narrative. Austin, TX: University of Texas Press.

Kim, Sue J. 2013b. “Introduction: Decolonizing Narrative Theory". Journal of Narrative Theory 42.3: 233-247.

Knopf, Marcy Jane. 1995. “Foreword to the 1995 Edition”. The Chinaberry Tree: A Novel of American Life \& Selected Writings. By Jessie Redmon Fauset. Boston, MA: Northeastern University Press. ix-xxix.

Kubota, Jennifer T., Mahzarin R. Banaji and Elizabeth A. Phelps. 2012. "The Neuroscience of Race". Nature Neuroscience 15.7: 940-948.

Larsen, Nella. 1929/2020. Passing. London: Penguin.

Mattan, Bradley D., Kevin Y. Wei, Jasmin Cloutier and Jennifer T. Kutoba. 2018. "The Social Neuroscience of Race-Based and Status-Based Prejudice”. Current Opinion in Psychology 24: 27-34.

McDowell, Deborah E. 1995. "The Changing Same”: Black Women's Literature, Criticism, and Theory. Bloomington, IN: Indiana University Press.

Mitchell, Jason P., Mahzarin R. Banaji and C. Neil Macrae. 2005. "The Link Between Social Cognition and Self-Referential Thought in the Medial Prefrontal Cortex". Journal of Cognitive Neuroscience 17.8: 1306-1315. 
Molenberghs, Pascal and Winnifred R. Louis. 2018. “Insights From fMRI Studies Into Ingroup Bias”. Frontiers in Psychology 9: 1868.

Moya, Paula. 2016. The Social Imperative: Race, Close Reading, and Contemporary Literary Criticism. Stanford, CA: Stanford University Press.

Omi, Michael and Howard Winant. 1994. Racial Formation in the United States: From the 1960s to the 1990s. New York: Routledge.

Palmer, Alan. 2004. Fictional Minds. Lincoln, NE: University of Nebraska Press.

Palmer, Alan. 2008. "Thought and Consciousness Representation (Literature)”. In: David Herman, Manfred Jahn and Marie-Laure Ryan (eds.). Routledge Encyclopedia of Narrative Theory. New York: Routledge. 602-607.

Pfeiffer, Kathleen. 2002. Race Passing and American Individualism. Amherst, MA: University of Massachusetts Press.

Prinz, Wolfgang, Friedrich Försterling and Petra Hauf. 2005. "Of Minds and Mirrors: An Introduction to the Social Making of Minds". Interaction Studies, 6.1: 1-19.

Reynolds, Guy. 1999. Twentieth-Century American Women's Fiction: A Critical Introduction. New York: St. Martin's Press.

Robinson, Amy. 1994. "It Takes One to Know One: Passing and Communities of Common Interest". Critical Inquiry 20.4: 715-736.

Roth, Philip. 1994. “Eli, the Fanatic”. In: Goodbye, Columbus. London: Vintage. 247-298.

Rottenberg, Catherine. 2008. Performing Americanness: Race, Class, and Gender in Modern African-American and Jewish-American Literature. Hanover, NH: University Press of New England.

Saucier, Donald A. 2015. "Race and Prosocial Behavior". In: David A. Schroeder and William G. Graziano (eds.). The Oxford Handbook of Prosocial Behavior. Oxford: Oxford University Press. 392-415.

Sherrard-Johnson, Cherene. 2007. Portraits of the New Negro Woman: Visual and Literary Culture in the Harlem Renaissance. New Brunswick, NJ: Rutgers University Press.

Sklar, Howard. 2013. The Art of Sympathy in Fiction: Forms of Ethical and Emotional Persuasion. Amsterdam: Benjamins.

Sylvander, Carolyn Wedin. 1981. Jessie Redmon Fauset, Black American Writer. Troy, NY: Whitston.

Tomlinson, Susan. 2002. "Vision to Visionary: The New Negro Woman as Cultural Worker in Jessie Redmon Fauset's Plum Bun”. Legacy 19.1: 90-97.

Wald, Gayle. 2000. Crossing the Line: Racial Passing in Twentieth-Century U.S. Literature and Culture. Durham, NC: Duke University Press.

Weik von Mossner, Alexa. 2014. Cosmopolitan Minds: Literature, Emotion, and the Transnational Imagination. Austin, TX: University of Texas Press.

Weik von Mossner, Alexa. 2016. "Feeling Cosmopolitan: Strategic Empathy in Charles W. Chesnutt's Paul Marchand, F.M.C.”. MELUS 41.4: 76-95.

Zunshine, Lisa. 2006. Why We Read Fiction: Theory of Mind and the Novel. Columbus, $\mathrm{OH}$ : Ohio State University Press.

Zunshine, Lisa. 2011. "Theory of Mind and Fictions of Embodied Transparency". In: Paula Leverage, Howard Mancing, Richard Schweickert and Jennifer Marston Williams (eds.). Theory of Mind and Literature. West Lafayette, IN: Purdue University Press. 63-92. 